\title{
Agenda Setting of Iraq Image in Malaysian English Newspaper
}

\author{
Hanaa Kadum Kassed ${ }^{1,2} \&$ Che Su Mustaffa ${ }^{1}$ \\ ${ }^{1}$ School of Multimedia and Technology and Communication, Universiti Utara Malaysia, UUM Sintok, kedah, \\ Malaysia \\ ${ }^{2}$ Ministry of Science and Technology, Baghdad, Iraq \\ Correspondence: Che Su Mustaffa, School of Multimedia and Technology and Communication, Universiti Utara \\ Malaysia, 06010 UUM Sintok, kedah, Malaysia. E-mail: chesu402@uum.edu.my
}

Received: September 8, 2014 Accepted: October 3, 2014 Online Published: December 20, 2014

doi:10.5539/ass.v11n2p225 URL: http://dx.doi.org/10.5539/ass.v11n2p225

\begin{abstract}
Mass media news on certain country itself can affect their image on society. The image that will appear could be positive, negative or neutral depending on the content in it. This study employs content analysis of Agenda Setting of Iraq image in Malaysian English newspapers indicated that NSTP and the Star. In total, 535 articles and news stories were obtained from three periods before, during and after the occupation of Iraq. Findings showed that the Agenda Setting for NSTP focused on the issue of "The Malaysia's policy towards Iraq", "The US policy and the occupation of Iraq" and "The impact of war on Malaysia". While, the Star focused on "Iraq's needs and suffering". In summary, the newspapers seem to take great care in transmitting images of other countries particularly the Islamic country, which could affect Malaysia and its neighbors politically, economically and socially. Thus it can be concluded that the media's ownership position plays vital role in shaping countries image in media coverage. The current study indicated that the positive and neutral image of Iraq in NSTP are considered important to the Malaysian government to advance its domestic and foreign policies to Malaysians, and also due to its political and economic interests with Iraq which is a Muslim country. Contrarily, the Star seemed to oppose government policies but this opposition is marginal and issue specific in nature depending upon the involvement of Malaysia interests and intensity of the government media differences on those issues.
\end{abstract}

Keywords: Iraq, Malaysia newspapers, agenda setting theory

\section{Introduction}

The occupation of Iraq in 2003 had resulted in the emergence of some images about Iraq in the media (Mockaitis, 2007). For example, George W. Bush mentioned, "a liberated Iraq can show the power of freedom to transform that vital region, by bringing hope and progress into the lives of millions". In addition, President George W. Bush told America on 22 March 2003 that, "Our mission is clear, to disarm Iraq of weapons of mass destruction, and to free the Iraqi people" (Cramer \& Thrall, 2012, p. 2). Even though there are studies that had looked at the image of Iraq, it is still worth noting that these studies had focused on the major role played by the Western media in shaping the issues of Iraq. Issues such as saving the Iraqi people, weapons of mass destruction were the focus of news in the Western media. In addition, issues regarding the soldiers of war and their victories, Iraq war as part of the war on terror, and pictures of crowds cheering US troops in Iraqi cities were highlighted by the Western media. Besides that, some other Western media also were not objective in reporting the issues of Iraq (Griffin, 2004; Hiebert, 2003; Dittmer, 2009; Zheng, 2006). The study aims to reveal the image of Iraq as portrayed by the Eastern media through the two Malaysian English newspapers, NSTP and the Star, which belong to two different political parties. NSTP is owned by United Malays National Organization (UMNO) and therefore reflects Malay ethnic views and the Star is owned by Malaysian Chinese Association, and therefore reflects Chinese ethnic views. The methodology used quantitative content analysis, to detect of Agenda Setting issues constructed by both newspapers about Iraq through before, during and after the occupation. Furthermore, detect the prominent Image categories constructed by both newspapers about Iraq through each period. This study was built upon the Agenda Setting function of media suggests that the more important the news media present a particular issue as being the more important that issue becomes for media consumers (McCombs as cited in Holody, 2011). In this case, the theory would suggest that a large amount of news coverage related to Iraq could result in media consumers considering the issue quite important (agenda-setting). Furthermore, the 
media's ownership position plays vital role in shaping countries image in media coverage.

\section{Studying on the Image of Iraq}

The conflict in Iraq was the most heavily covered war by the news media, where it can be accessed through sources like, local, national, and international online news sites, online communities, and weblogs (Carpenter, 2007). Thus, some images about Iraq emerged during the occupation of the US, for example, Largio (2004) stated that the rationales for the war on Iraq, there were; the war on terror, the desire to prevent the proliferation of weapons of mass destruction, liberating the people of Iraq and the imminent threat that Iraq posed. Stover, Megally and Mufti (2005) stated that Iraqis would rush to the streets to welcome American soldiers as they rode triumphant into the Iraqi capital as liberators. According to Barnathan (2004) in his article, he further explained the reasons and the justifications for the US intervention in the Iraq war: it focuses on terrorist organizations and the countries supporting them. Besides, the article also focuses on the war against terrorism and how it was turned into a war against Afghanistan which was seen as the operating center of al Qaeda and then the war against Iraq, which was said to have a link with weapons of mass destruction that could reach up to the hands of the terrorists.

Ahmad (2008) examined the coverage pattern of The New York Times and The Toronto Star from 1 March 2003 to 15 April 2003 regarding coverage of antiwar protests and the coverage of Iraq war. He used quantitative and qualitative methods of content analysis of news stories published on front pages. He found that The New York Times relied on official sources more than Toronto Star due to the fact that the US press relied more on official sources while reporting foreign policy issues. Coverage of anti-war protests in The Toronto Star was more vigorous and blunt while The New York Times consciously undermined antiwar coverage. The news stories related to anti-war protests and civilian casualties in Iraq have been marginalized in The New York Times, whereas the news stories related to weapons of mass-destruction (WDM) including chemical and biological weapons, and the war being for the liberation of the Iraqi people not for the US strategic and economic interests in the region have been magnified. On the contrary, The Toronto Star's coverage was more balanced and its stories contained a different point of view. The Toronto Star coverage was on anti-war protests; it reported more on the deaths of Iraqi civilian population, and gave more coverage to Canadian government's position regarding this issue. Finally, it was found that coverage of the Iraq war got the maximum attention of both newspapers.

Fried (2005) examined terrorism as a context in the major newsmagazines' coverage of Iraq in the pre-war period. He used content analysis of Time and Newsweek from September 2002 because it marked the start of a new effort by the Bush administration to promote support for its Iraq enterprise, and from the first issue of January 2003 to March 24, 2003 in which the first month of 2003 marked the final run-up to war. It included analysis of the issues' cover art, graphics within news stories, and Iraq and terrorism stories. He found that during this period, news magazines frequently juxtaposed terrorism and Iraq and used graphics that linked Iraq to terrorism and terrorists.

Zeidan (2005) focused his research to answer the question of what are the perceptions of Germany toward the image of Iraqi. His methodology involved distribution of 286 questionnaires. Twenty-eight were distributed to same average-sized cities whereas 30 were distributed the major cities. He found that the image of the Iraqi citizen was distorted and focused on the emotional side of the view such as looting and kidnapping foreigners which led to an impression that the Iraqis are characterized by those attributes and their positive side is not highlighted. Finally, he concluded that the distorted image of the Iraqi people in Germany was due to the absence of the Iraqi media in Germany and the weakness of personal contact, although there are a number of Iraqis in Germany, as well as the weakness of the Iraqi diplomatic side in Germany.

Dittmer (2009) examined how the news media and US officials within the Bush administration utilized rhetoric and specific words over others to frame the violence and civil unrest in Iraq following the US invasion. He used a qualitative content analysis method to analyze briefing transcripts from the Department of Defense archives between May 2003 and October 2006 and quantitative content analysis to analyze 254 stories from the New York Times and The Washington Post between May 2003 to April 2004 and November 2005 to October 2006. The analysis revealed that officials framed Iraq's insurgency as part of the war on terror and the insurgency frame emerged in print during the periods of study.

Finally, since the conflict in Iraq was the most heavily covered war by the news media, it can be said that the Western media had played a major role in shaping the image of Iraq by focusing on frameworks such as the war was necessary to save the Iraqi people, and the search for weapons of mass destruction. Therefore, there are consistent arguments pertaining to the media's conformity to foreign policy. The media's advocacy of Bush administration policy towards Iraq was at the expense of basic journalistic principles and media credibility and 
quite a few scholars labeled them as lies (Zheng, 2006; Hiebert, 2003; Largio, 2004).

\section{Agenda Setting Theory}

It can be said that the roots of the Agenda Setting Theory are from Lippmann (1922); he said the news media are a primary source of the pictures in our heads. Specifically, the Agenda Setting Theory is a theory about the transfer of salience from the mass media pictures of the world to the pictures in our heads. The core theoretical idea is that elements prominent in the media picture become prominent in the audience's picture. Those elements emphasized in the media agenda come to be regarded as important by the public (Mccombs, 2004). McCombs and Shaw conducted an empirical study to investigate the agenda-setting capacity of the mass media in Chappel Hill during the US presidential elections in 1968. They found that the mass media determined the important issues; that is the media determination agenda of the campaign (McCombs \& Shaw, 1972).

According to Kensicki (2000), the Agenda Setting Theory focuses on the media telling the public what to think about (first level), and also how to think about it (second level). It can be said that in Agenda Setting, readers learn not only about a given issue, but also how important it is to attach to that issue from the amount of information received. Shaw (1979) indicated that the theory assumes that the mass media make people know or do not know, interested in or ignore general issues. People tend to accept what the media offers and also tend to focus on what the media focuses on. The media does not affect people's attitudes, but their awareness. It helps by arranging and organizing the priorities of the issues that must be understood instead of dealing with a wide range of issues.

The fact that the first level of Agenda Setting Theory focuses on object salience means that it focuses on what we think about issues. The media coverage of a specific issue makes it important. Thus, the public knows the importance of the issues on the basis of quantity of coverage of the issues (Wanta, Golan, \& Lee, 2004). So, the current study focuses on the first level of Agenda Setting Theory, due to specifically focusing on the agenda setting function of the media, Lang and Lang observe: "The mass media force attention to certain issues. They build up public images of political figures. They are constantly presenting objects suggesting what individuals in the mass should think about, know about, have feelings about" (McCombs \& Shaw, 1972, p. 177).

Muin (2011) examined the media agenda setting theory and its application to the issues of the Iraq War, weapons of mass destruction and the attacks of September 11, in order to know if is there a correlation between media agenda-setting and public agenda building. He analyzed various media forms during three periods following the attack of September 11. The result depicted a strong correlation between media agenda setting and public agenda building.

Lee (2004) focused on the coverage of the Iraqi war in the New York Times, The Arab News, and the Middle East Times. He used quantitative content analysis on articles, editorials and opinion/Column of 502, from the start of the war on March 20, 2003 to the end of the war on May 1, 2003. His results indicated that The New York Times focused to US war efforts, while the Arab newspapers focused to antiwar voices. The New York Times depended US officials for sources, whereas the Arab newspapers depended on Arab sources. Also, the coverage of The New York Times was more thematic than the Arab newspapers. With regard to how the war was described, The New York Times focused on the purpose of the war according to the US administration whereas the Arab papers focused on aggressive and illegitimate aspects of the war. Finally The New York Times focused more on the process of combat, US led construction of post-war Iraq, military operation, and war victims of coalition forces in versus the Arab newspapers which focused on antiwar demonstrations or responses, war effects on society, and Iraqi victims.

Idid and Kee (2012) used content analysis and survey to study the media and the Agenda Setting between the Malays and Chinese during the 2008 election. Content was analyzed in six newspapers, namely Utusan Malaysia, Berita Harian, Sin Chew Daily, Nanyang Siang Pau, the Star, and New Straits Times. They found 9,135 news items from 24 February to 8 March 2008. They surveyed 1,454 respondents and found that there was no relationship between the Malay media and the Malay society, which meant the Malay media, did not focus on issues that were of interest to the Malay readers during election time. However, they found a relationship between the Chinese media and Chinese society, which meant that the Chinese media focused on issues that were of interest to the Chinese readers during election time.

To sum up, according to Lippmann (as cited in Mccombs, 2004), the Agenda Setting Theory was used to determine what the public takes to be important. This particular study analyzed the agenda of Malaysian English newspapers regarding the coverage of Iraq issues. It will look at what issues the agenda media focuses on and which prevalent issues are constructed by Malaysian English newspapers. By looking at this focus, we can see how the image of Iraq is being portrayed in Malaysian English newspapers. 


\section{Malaysian Press}

Hamzah $(2008,2009)$ identified four varieties of rotating media; the first type is in the dominance of the economic elite on the media, such as Russia, while the second type is regarding controlling the political elite on the media such as South Korea, Taiwan and Malaysia. The third type is a system and the media in some countries like in Latin America, while the fourth type is the traditional dominance of liberalism in contemporary Europe such as Sweden and Britain.

The role of the media in Malaysia is shaped not only to disseminate information and to educate as envisaged in the government's policy, but also to guide the people to walk hand in hand with the government's aspiration and policy, to be able to be sustained and survive in the media industries (Ahmad, Kee, Mustaffa, Ibrahim, Wan Mahmud, \& Dafrizal, 2012). In Malaysia, the function of the media is to support the goals of the government, as well as assist in promoting the spirits of friendship and unity among the people (Ibrahim, Mustaffa, Kee, \& Ahmad, 2011).

The Malaysian government began to control the media gradually since the declaration of Independence in 1957 , because it is not ready for the freedom of expression, which leads to political instability and unrest between the races and this consequently leads to the obstruction of economic development. There has been a restriction in the freedom of the press in Malaysia. According to Sani (2004, p. 345), media freedom criteria in Malaysia included: i. Mass media control through laws that cover allegation, compensation, confidentiality, security and licensing; ii. Favouritism in choosing and broadcasting or publishing any public news; iii. Permission to use international of foreign news agency services; iv. Licensing rights of printed publication; v. Distribution and dissemination of publications; and vi. Freedom to criticize issues in relation to the government, government agencies, regional agencies, and civil servants.

Sani (2004) believed that the issue of race is used as a motive for the control of the press in Malaysia because their purpose is to support the government's policy in order to achieve its goals. Despite the existence of restrictions in the media in Malaysia, it cannot be denied that there is some space enabling journalists to take advantage of them, especially as the government, society and the media itself are subject to significant transformations (Rajaratnam, 2009).

To sum, the existence of political control over Malaysian media could be due to the fact that system of the media in the Malaysian society is an important factor for social, political, economic, and cultural change and if it is used incorrectly, it can lead to a destabilization of the society. In addition, the media's commercial growth in Malaysia has been matched by the progressive introduction of stricter legislation controlling its output. These conditions have led to more censorship and shrinking democratic space for the media. Furthermore, Malaysian government prohibits stories that are related to race, religion or the problems of foreign countries because of the religious and ethnic composition of the mixed population of the country and their sensitivity, as well the relationship with neighboring countries.

\section{The Present Study}

This study employed a quantitative content analysis to investigate the hypothesis and research questions as quantitative content analysis is proven to be a more powerful method than survey and interview because of its unobtrusive nature and its lack of reliance on subjective perception (Boettger \& Palmer, 2010). Content analysis is popular with mass media researchers because it is an efficient way to investigate the content of the media (Wimmer \& Dominick, 2006). Morris (1994) described content analysis as a research technique used to objectively and systematically make inferences about the intentions, attitudes, and values of individuals by identifying specified characteristics in textual messages. Therefore, content analysis is used in this research because: first, it allows the analysis of words and concepts, texts, and thereby helping to answer the research questions (Content analysis, 2012). Second, because using archival materials is possible, the content analysis is also suitable for longitudinal studies (Riffe, Lacy, \& Fico, 2005).

This study analyses the publication of news stories and articles in the NSTP and the Star newspaper during a specific period. The sample was collected from the published news stories and articles during the three periods (before the occupation 15 January 2002 until 8 April 2003, during the occupation 9 April 2003 until 28 June 2004 and after the occupation 29 June 2004 until 18 September 2005) of both newspapers.

The selection was based on purposive sampling that involves a deliberate choice of an informant due to the fact that it provides more accurate results and that it would quickly lead to the main targets (Tongco, 2007).

The unit of analysis for this study is the whole text, to see what the dominant focus in the whole text is. Ibrahim, Mustaffa, and Kee (2010) also believed the whole text is suitable to see what the dominant focus in the whole 
news stories and articles is. The statistics are necessary to understand the scientific method of knowing because they allow researcher to make conclusion about the sample. The analyses were used One sample nonparametric tests based on Binomial test between two categories comparison, and Chi-square test for more than two categories were used for the data analysis in this study because the variables use nominal data (Gibbons \& Chakraborti, 2011; SPSS base 10.0 user's guide, 1999).

The researchers depend on the previous studies to find the major categories while the subcategories are developed by analyzing text content, news stories and articles. The major categories are: image categories and Agenda Setting issues, while each major category can be divided into some subcategories as follows:

Image: perception of Malaysian newspaper toward Iraq in terms of historical, political, economic, military, diplomatic and religious aspects, which will be measured as positive, negative and neutral. Drawing from the research on inter-nation images, the authors (Galal, Galander , \& Auter, 2008; Küçükcan, 2010) proposed image which adopted in this research:

Positive image: Publication that shows favorable and supportive view towards Iraq, such as the resistance and the opposition of some countries to the occupation; Negative image: Publication that shows unfavorable and opposed view towards Iraq, such as the effects of the damaged health system on Iraqi women and children. It also includes news on the humiliation of the captives in Abu Ghraib prison due to organized abuse and torture from American guards; Neutral image: Publication that is neither positive nor negative. Examples of such image include news about the occupation of Iraq without authorization from the United Nations and how the weapons of mass destruction was used as an excuse for the sanctions and the invasion of Iraq.

Agenda Setting Issues: refers to and focuses on a particular issue of Iraq, which means that Agenda Setting Theory refers to issue which we must think about. This study investigates four issues, namely, "The US policy and the occupation of Iraq" This issue refers to invasion of Iraq without a UN mandate and under the excuse of weapons of mass destruction which later led to resist occupation. It also refers to US double-standard policy which was evidenced by its support for Israel's occupation of Palestine, and to the invasion of Iraq as an occupation, not liberation; "Iraq's needs and suffering" This refers to the suffering the Iraqi people faced before, during and after the US occupation. As a result of the military disaster which have taken the lives of a number of innocent civilians (women and children), Iraqis needed food, shelter, medicine, sanitation, electricity, safety and security; "The Malaysia's policy towards Iraq" refers to Malaysia rejecting the US policy towards the Middle East, and to show support for Iraq and Palestine, Malaysia is against the war and occupation of Iraq; and "The impact of war on Malaysia" refers to the impact of the Iraq war on the Malaysian economy and Malaysians living in Iraq and the neighboring countries of Iraq. These issues were selected because these were the most covered issues during the periods studied.

\section{Research Findings}

A total of 535 articles and news stories were collected relevant to the present study. The majority of the news items came from the NSTP newspaper $323(100.0 \%)$ indicates that the period before the occupation has the highest number with $146(45.2 \%)$ articles and news stories, followed by the period during the occupation 111 (34.4\%) articles and news stories, and the period after the occupation as the lowest with 66 (20.4\%) articles and news stories. while the Star newspapers through the three periods was $212(100.0 \%)$. A total of $100(47.2 \%)$ articles and news stories were published for the period before the occupation, $82(38.7 \%)$ articles and news stories for the period during the occupation and $30(14.2 \%)$ articles and news stories for the period after the occupation.

Table 1. Total of articles and news stories for NSTP and the Star in the three periods

\begin{tabular}{lllll}
\hline Newspaper & Before & During & After & Total \\
\hline \multirow{2}{*}{ NTSP } & $146(45.2 \%)$ & $111(34.4 \%)$ & $66(20.4 \%)$ & $323(100.0 \%)$ \\
\multirow{2}{*}{ The Star } & $100(47.2 \%)$ & $82(38.7 \%)$ & $30(14.2 \%)$ & $212(100.0 \%)$ \\
\multirow{2}{*}{ Overall } & $246(100.0 \%)$ & $193(100.0 \%)$ & $96(100.0 \%)$ & $535(100.0 \%)$ \\
& $146(45.2 \%)$ & $111(34.4 \%)$ & $66(20.4 \%)$ & $323(100.0 \%)$ \\
& $100(47.2 \%)$ & $82(38.7 \%)$ & $30(14.2 \%)$ & $212(100.0 \%)$ \\
\hline
\end{tabular}

The analysis conducted between the two newspapers on agenda setting issues for the period before the 
occupation, refers to the issue of "The Malaysia's policy towards Iraq" published by NSTP were 44 (53.0\%) news, as compared to the Star $39(47.0 \%)$. Similarly, the issue relating to "The US policy and the occupation of Iraq" covered 63 news $(71.6 \%)$ in the NSTP compared to $25(28.4 \%)$ in the Star. Also, the issue related to "The impact of war on Malaysia" was featured in NSTP in 37(67.3\%) articles and news stories, more than the Star which only published $18(32 \%)$ articles and news stories for the periods concerned. On the contrary, the issue related to "Iraq's needs and suffering" was published by the Star in 18 news $(90.0 \%)$ which is more than NSTP which only published $2(10.0 \%)$ news.

Table 2. The agenda setting issues before the occupation between NSTP and the star

\begin{tabular}{lllll}
\hline Categories & Newspaper & Frequency & Percentage & Total \\
\hline \multirow{2}{*}{ Iraq's needs and suffering } & NSTP & 2 & $10.0 \%$ & \multirow{2}{*}{$20(100.0 \%)$} \\
\multirow{2}{*}{ The Malaysia's policy towards Iraq } & The Star & 18 & $90.0 \%$ & \\
& NSTP & 44 & $53.0 \%$ & \multirow{2}{*}{$83(100.0 \%)$} \\
The US policy and the occupation of Iraq & The Star & 39 & $47.0 \%$ & \\
& NSTP & 63 & $71.6 \%$ & \multirow{2}{*}{$88(100.0 \%)$} \\
The impact of war on Malaysia & The Star & 25 & $28.4 \%$ & \\
& NSTP & 37 & $67.3 \%$ & $55(100.0 \%)$ \\
\hline
\end{tabular}

Meanwhile, the period of during the occupation shows that there is little difference in the Agenda Setting issues published by both newspapers. The Star was found to be more focused on articles and news stories about two issues which are "Iraq's need and Suffering" and "The impact of war on Malaysia" with $30(61.2 \%)$ and 25 $(59.5 \%)$ news stories published respectively. Meanwhile, NSTP published $19(38.8 \%)$ and $17(40.5 \%)$ articles and news stories respectively. While the issue of "the Malaysia's policy Towards Iraq" was published more in NSTP compared to the Star with 31(66.0 \%) and $16(34.0 \%))$ articles and news stories respectively. Also, the issue of "The US policy and the occupation of Iraq", NSTP published more compared to the Star with 44(80.0\%) and $11(20.0 \%)$ articles and news stories respectively.

Table 3. The agenda setting issues during the occupation between NSTP and the star

\begin{tabular}{lllll}
\hline Categories & Newspapers & Frequency & Percentage & Total \\
\hline \multirow{2}{*}{ Iraq's needs and suffering } & NSTP & 19 & $38.2 \%$ & \multirow{2}{*}{$49(100.0 \%)$} \\
\multirow{3}{*}{ The Malaysia's policy towards Iraq } & The Star & 30 & $61.2 \%$ & \\
& NSTP & 31 & $66.0 \%$ & \multirow{2}{*}{$47(100.0 \%)$} \\
\multirow{2}{*}{ The US policy and the occupation of Iraq } & The Star & 16 & $34.0 \%$ & \\
\multirow{2}{*}{ The impact of war on Malaysia } & NSTP & 44 & $80.0 \%$ & \multirow{2}{*}{$55(100.0 \%)$} \\
& The Star & 11 & $20.0 \%$ & \\
& NSTP & 17 & $40.5 \%$ & \multirow{2}{*}{$40(100.0 \%)$} \\
\hline
\end{tabular}

Looking at the prominent issues constructed by NSTP and the Star for the period after the occupation, the analysis shows NSTP published more news related to the issue of "Iraq's need and Suffering" with 18 (54.5\%) news compared to the Star which published 15 (45.5\%). The issue of "Malaysia's policy toward Iraq" was published more in NSTP with 21(84.0\%) articles and news stories compared to the Star with only $4(16.0 \%)$ articles. Next, the issue "The US policy and the occupation of Iraq" was published more in NSTP than the Star with $24(82.8 \%)$ and 5(17.2\%) articles and news stories respectively. While the issue of "The impact of war on Malaysia" was published more in the Star compared to NSTP with $6(66.7 \%)$ and $3(33.3 \%)$ articles and news stories respectively. 
Table 4. The agenda setting issues after the occupation between NSTP and the star

\begin{tabular}{lllll}
\hline Categories & Newspapers & Frequency & Percentage & Total \\
\hline \multirow{2}{*}{ Iraq's needs and suffering } & NSTP & 18 & $54.5 \%$ & \multirow{2}{*}{$33(100.0 \%)$} \\
\multirow{2}{*}{ The Malaysia's policy towards Iraq } & The Star & 15 & $45.5 \%$ & \\
& NSTP & 21 & $84.0 \%$ & \multirow{2}{*}{$25(100.0 \%)$} \\
\multirow{2}{*}{ The US policy and the occupation of Iraq } & The Star & 4 & $16.0 \%$ & \\
\multirow{2}{*}{ The impact of war on Malaysia } & NSTP & 24 & $82.8 \%$ & \multirow{2}{*}{$29(100.0 \%)$} \\
& The Star & 5 & $17.2 \%$ & \\
& NSTP & 3 & $33.3 \%$ & \multirow{2}{*}{$9(100.0 \%)$} \\
\hline
\end{tabular}

While the next analysis conducted between the two newspapers on image categories for each periods, indicates that the period before the occupation both newspapers published almost equal positive articles and news stories about Iraq, with NSTP publishing $40(47.1 \%)$ and the Star $45(52.9 \%)$ news. While the analysis indicated that majority of articles and news stories published by the Star were negative, it was found that NSTP published a smaller number of negative articles and news stories. There were $25(75.8 \%)$ articles and news stories published in the Star compared to only 8 (24.2\%) in NSTP. Next, neutral image was dominant in NSTP with 98 (76.6\%) articles and news stories compared to 30 (23.4) articles and news stories in the Star.

Table 5. The image categories before the occupation between NSTP and the star

\begin{tabular}{lllll}
\hline Categories & Newspapers & Frequency & Percentage & Total \\
\hline \multirow{2}{*}{ Positive } & NSTP & 40 & $47.1 \%$ & $85(100.0 \%)$ \\
& The Star & 45 & $52.9 \%$ & \\
\multirow{2}{*}{ Negative } & NSTP & 8 & $24.2 \%$ & $33(100.0 \%)$ \\
& The Star & 25 & $75.8 \%$ & \\
& NSTP & 98 & $76.6 \%$ & $128(100.0 \%)$ \\
\hline
\end{tabular}

For the period during the occupation, NSTP published more positive image by publishing $36(69.2 \%)$ articles and news stories about Iraq compared to the Star with only $16(30.8 \%)$ articles and news stories in the same category. On the other hand, the Star newspaper published 48(71.6\%) negative articles and news stories compared to only 19 (28.4\%) negative articles and news stories in NSTP. A total of 56 (75.7\%) articles and news stories were published using the neutral image in NSTP, more than the Star which only published 18(24.3\%) articles and news stories in the same category.

Table 6. The image categories during the occupation between NSTP and the star

\begin{tabular}{lllll}
\hline Categories & Newspapers & Frequency & Percentage & Total \\
\hline \multirow{2}{*}{ Positive } & NSTP & 36 & $69.2 \%$ & $52(100.0 \%)$ \\
& The Star & 16 & $30.8 \%$ & \\
\multirow{2}{*}{ Negative } & NSTP & 19 & $28.4 \%$ & $67(100.0 \%)$ \\
& The Star & 48 & $71.6 \%$ & \\
& NSTP & 56 & $75.7 \%$ & $74(100.0 \%)$ \\
\hline
\end{tabular}

In general, for the period after the occupation, the result of analysis also showed that positive image was the highest in NSTP with $22(81.5 \%)$ articles and news stories, versus the Star which only published $5(18.5 \%)$ articles and news stories in the same category. For the negative image was the highest in the Star with 17(54.8\%) articles and news stories, versus NSTP with 14(45.2\%) articles and news stories. For the neutral image, NSTP published $30(78.9 \%)$ articles and news stories, versus the Star 8 (21.1\%) articles and news stories. 
Table 7. The image categories after the occupation between NSTP and the star

\begin{tabular}{lllll}
\hline Categories & Newspapers & Frequency & Percentage & Total \\
\hline \multirow{2}{*}{ Positive } & NSTP & 22 & $81.5 \%$ & $27(100.0 \%)$ \\
& The Star & 5 & $18.5 \%$ & \\
\multirow{2}{*}{ Negative } & NSTP & 14 & $45.2 \%$ & $31(100.0 \%)$ \\
\multirow{2}{*}{ Neutral } & The Star & 17 & $54.8 \%$ & \\
& NSTP & 30 & $78.9 \%$ & $38(100.0 \%)$ \\
\hline
\end{tabular}

In running the One sample nonparametric tests based on Chi-square test for more than two categories comparison, it was found that the total number of articles and news stories published by each period, the highest number of articles and news stories was published in the period before the occupation with $146(45.2 \%)$ news, and the lowest in the period after the occupation with only $66(20.4 \%)$ news. The one sample Chi Square test revealed a significant difference to the total number of articles and news stories in NSTP (sig. $0.000, p \leq 0.05$ ). It was found that articles and news stories published decreased gradually through the three periods. While the total number of articles and news stories published in the Star by each period, in which the highest number was recorded in the period before the occupation with $100(47.2 \%)$ news stories and articles, and the lowest was recorded in the period after the occupation with $30(14.2 \%)$ news stories and articles. The one sample Chi Square test revealed a significant difference between the Star and periods, where significant emerged (sig. 0.000, $\mathrm{p} \leq 0.05)$.

In running the One sample nonparametric tests based on Binomial test between two categories comparison, test was conducted on the four Agenda Setting issues in the two newspapers in the period before the occupation, and it was found that three of them emerged significant. The result indicated that the issue of "Iraq's needs and suffering" was published more in the Star compared to NSTP, thus, significant results emerged (sig. 0.000, $\mathrm{p} \leq 0.05$ ). The second issue "The US policy and the occupation of Iraq" was published more in NSTP compared to the Star, so significant results emerged (sig. 0.000, $p \leq 0.05$ ). Similarly, the third issue "The impact of war on Malaysia" was published more in NSTP compared to the Star, so significant results emerged in the sample (sig. $0.015, \mathrm{p} \leq 0.05)$. Contrarily, the test on the issue of "The Malaysia's policy towards Iraq" revealed no significant difference (sig. 0.661, $\mathrm{p} \leq 0.05$ ).

The result for the period during the occupation indicated that NSTP published more news on the issue "The Malaysia's policy towards Iraq" compared to the Star, so the one sample Binomial test revealed that significant results emerged (sig. 0.041, $\mathrm{p} \leq 0.05$ ). Significant results also emerged (sig. $0.000, \mathrm{p} \leq 0.05$ ) for the issue "The US policy and the occupation of Iraq" in which NSTP published more news than the Star. Whereas no significant differences were found for the issues "Iraq's needs and suffering" and "The impact of war on Malaysia".

The result for the period after the occupation findings showed that the issue of "The Malaysia's policies towards Iraq" was published more in NSTP compared to the Star. Hence, significant results emerged (sig. 0.001, $p \leq 0.05$ ). The second issue which was "The US policy and the occupation of Iraq" also was published more in NSTP compared to the Star, so significant results emerged (sig. 0.001, $\mathrm{p} \leq 0.05$ ). On the contrary, no significant differences were found for the issues "Iraq's needs and suffering" and "The impact of war on Malaysia" as the two issues appeared to be convergent in both newspapers.

In terms of the two newspapers on image categories for each period, for the period before the occupation the results of the One Sample Binomial test indicated that there was a significant difference between NSTP and the Star regarding neutral image (sig. 0.000, $\mathrm{p} \leq 0.05$ ). The negative image also showed a significant difference between NSTP and the Star, so significant result emerged (sig. 0.005, $\mathrm{p} \leq 0.05$ ). On the other hand, the positive image showed no significant differences between NSTP and the Star.

The One Sample Binomial test was run to test the significant difference for each image category published by both newspapers in the period during the occupation. The positive image category about Iraq was published more in NSTP than the Star, thus the significance emerged (sig. 0.008, $\mathrm{p} \leq 0.05$ ). Similarly, the neutral image about Iraq was published more in NSTP than the Star and thus significant result emerged (sig. 0.000, p $\leq 0.05$ ). In contrast, the Star published more negative image on Iraq than NSTP and the significance emerged (sig. 0.001, $\mathrm{p} \leq 0.05)$.

For the period after the occupation the data revealed that positive and neutral image about Iraq was published 
more in NSTP compared to the Star, thus the one sample Binomial test revealed that significant result emerged for positive image (sig. $0.002, p \leq 0.05$ ) and neutral image (sig. 0.001, $\mathrm{p} \leq 0.05$ ). Thus, there was a significant difference of image categories in the period after the occupation between NSTP and the Star for positive and neutral image, while there was no significance for negative image.

\section{Discussion}

The analyses showed significant differences in the Malaysian newspapers coverage on Iraq's crisis through the volume of coverage. With regard to the difference of total number of articles and news stories published by NSTP and The Star, it was clear from the findings that the total number of articles for NSTP and the Star by the three periods decreased gradually. This could be attributed to the war's longevity and the lack of coverage of the topic as the war progressed (Fritz, 2011). This may also be due to the fact that the Malaysian government played fewer roles with the passage of time due to the formation of the new Iraqi government after the occupation of Iraq, therefore attributed the cause of the gradual decrease.

With regard to the results for the differences between prominent issues constructed by NSTP and the Star newspapers through each period, the findings revealed significant differences. Before the occupation, the category of "Iraq's needs and suffering" was published in the Star more than NSTP. This was due to the fact that the Star focused more about human issues, this finding is consistent with the research conducted by Sern and Zanuddin (2011) examined the perception, visibility and reach of the social marketing programmers of AIDS patients in the Malaysian media through Agenda Setting. The methodology they used was the quantitative content analysis of three selected Malaysian newspapers (Utusan Malaysia, the Star, and Sin Chew Jit Po). Throughout the six months period, in 49 articles they found that the Star gave the most predominance in news coverage with the greatest number of visibility of social marketing programs for AIDS patients and HIV/AIDS-related news articles.

In contrast, the issue of "The US policy and the occupation of Iraq" and "The impact of war on Malaysia" were more prominent in NSTP compared to the Star in the period before the occupation. With regard to the issue of "The US policy and the occupation of Iraq", the events of 11 September 2001 led to a change in the relationship between the United States and Malaysia, due to the fact that America emerged as the only superpower since the collapse of the Soviet Union. Thus United States had a change in its foreign policy toward the world. This is evident through Bush's decision to liberate Iraq without the UN's permission (Khalid, 2003). Obviously, Malaysia refused this unipolar policy toward Iraq and the world.

With regard to the issue of "The impact of war on Malaysia" it is not surprising that NSTP published more news on this, considering that the largest ruling political party, UMNO controls the New Straits Times Press (Halim, 2012), and it targeted the issue of how the government handled the economy by taking the necessary measures to cushion the effects of war in order not to affect the popularity of the government (Suffian, n. d.).

For the period during the occupation, it revealed significant differences in two issues which are "The Malaysia's policy towards Iraq" and "The US policy and the occupation of Iraq" in which NSTP published more news than the Star. The reason for this trend is that majority of Malaysian Muslim population are against the US invasion of Iraq (Smith, 2003). Another reason for Malaysia's opposition to the war in Iraq was because it viewed Washington's policy as the one that represented war against Islam (Liow, 2003).

For the period after the occupation, the two issues which were dominant in NSTP are "the US policy and the occupation of Iraq". This is because the end of the political phase of US occupation did not erase the most pressing problems confronting Iraq as shattered state as a result of US miscalculations hubris (Diamond, 2004). In addition, the US attack on Iraq was done without the U.N's permission and therefore it was a violation of international law (Liow, 2003). Thus, the focus to this issue reflects the position of Malaysia which refused this US policy toward Iraq and the world.

The second issue which is dominant in NSTP is "the Malaysia's policy towards Iraq". This might be due to the fact that the role of the media in Malaysia is shaped not only to disseminate information and to educate as envisaged in the government's policy, but also to guide the people to walk hand in hand with the government's aspiration and policy (Ahmad, Kee, Mustaffa, Ibrahim, Wan Mahmud, \& Dafrizal, 2012). Thus the function of the media in Malaysia is to support the goals of the government and in this case, the Malaysian government had opposed military action against Iraq by the US (Ibrahim, Mustaffa, Kee, \& Ahmad, 2011).

Further, the results show some differences in prominent image constructed by both newspapers through each period. It seems clear from the finding that there were more neutral images in NSTP than the Star in the period before the occupation. This might be due to the fact that NSTP represents the ruling party, thus reflects the 
Malaysian government's foreign policies. This supports the argument that media buttresses the interests of the ruling class and works as a propaganda organ of the state (Ahmad, 2008). In contrast, the Star published more negative image of Iraq than NSTP. One explanation that can be offered for the negative image in the Star is, it is dependent on international news agencies whose coverage about foreign countries, including Muslim was negative (Ibrahim \&Hashim, 1996).

While for the period during and after the occupation, the news published by NSTP was more positive and neutral image compared to the Star. This is because of the relationship between Iraq and Malaysia (cultural and commercial) which was seen through Malaysian students studying in Iraq, and negotiation about on palm oil (Harun, 2009). This is similar to the findings of a study by Li (2012) who examined the coverage of China in Australia through these five dimensions: military, economic, cultural, political and environmental. His result showed the positive and neutral representations of China are attributed to stronger commercial links and frequent cultural exchange between China and Australia.

The Star published more articles and news stories that fall into negative image categories compared to NSTP in the period during the occupation. This is because the Star showed images of dead or wounded Iraqi people. Another reason is maybe it was heavily influenced by newsroom culture, and their preconceived understandings of the war. This is similar to findings of a study done by Cooper and Kuypers (2004) which found the stories reported by behind-the-lines journalists tended to be more negative, because the embedded journalists explained their stories often by underlining the heroic and human angle of the US troops, while the stories from behind-the-lines journalists were generally more critical and more sympathetic to the Iraqi civilians on the ground.

To summarize, NSTP published more news which are more related to the government policy while the Star published less news related to the government policy, and therefore it might have emphasized publications as a reflection of official Malaysian policies especially the Malaysian government had opposed military action against Iraq by the US. Further, Malaysia have a good relation with Iraq due to political and economic interests. Besides, Iraq is a Muslim country. In other words, NSTP was seen to support Malaysia's policies on foreign affairs and framed foreign counties images accordingly to government's interests. Contrarily, the Star opposed government policies but this opposition is marginal and issue specific in nature depending upon the involvement of Malaysia interests and intensity of the government media differences on those issues.

In summary, the readers of newspapers learn about issues of significance to their communities, and how much importance to attach to the issues, based on the amount of coverage given to them. Newspapers play a central role in shaping political and social reality because the editors and publishers are usually members of the elite. It is worth noting that the public's concern for certain issues (the public agenda) actually drives what the media elects to cover (the media agenda) that is, media coverage tends to be market driven.

Agenda setting is a significant part of the surveillance role because it contributes substantial portions of our pictures about the larger environment. And recent research on the consequences of both first level and second-level agenda-setting effects outlined significant influence on attitudes and opinions. Thus, the agenda-setting effects of the mass media also have significant implications beyond the pictures created in people's heads. In the original traditional domain of agenda-setting, the salience of public issues, there is considerable evidence that the shifting salience of issues on the media agenda often is the basis for public opinion.

Therefore, future research should consider first, qualitative content analysis as it may possibly give more observation about the coverage of the both newspapers; second, more research will enhance our understanding of how the media make certain aspects of war appear more significant or appear more salient. What most people know of war comes from the media, yet what we know is so little. If presented with more information with images and with more visual, what we think we know could change; third, to what extent do the images of Iraq portrayed by the two newspapers depend on international news agencies. Future research could describe the dominant images portrayal of Iraq, and also find out which one depends more on these agencies.

\section{References}

Ahmad, F., Kee, C. P., Mustaffa, N., Ibrahim, F., Wan Mahmud, W., \& Dafrizal. (2012). Information Propagation and the Forces of Social Media in Malaysia. Asian Social Science, 8(5), 71-76. http://dx.doi.org/10.5539/ass. v8n5p71

Ahmad, H. M. (2008). War in Iraq: Comparative Coverage of the Toronto Star and The New York Times. Canadian Journal of Media Studies, 3(1), 33-56. 
Barnathan, G. P. (2004) .The War against Iraq and International Order: From Bull to Bush. International Studies Review, 6(2), 195-212. http://dx.doi.org/10.1111/j.1521-9488.2004.00395.x

Boettger, R. K., \& Palmer, L. A. (2010). Quantitative Content Analysis: Its Use in Technical Communication. Transactions on Professional Communication, 53(4), 346-357. http://dx.doi.org/10.1109/TPC.2010. 2077450

Carpenter, S. (2007). U.S. Elite and Non-elite Newspapers' Portrayal of the Iraq War: A Comparison of. Journalism \& Mass Communication Quarterly, 84(4), 761-776. http://dx.doi.org/10.1177/1077699007 08400407

Conover, W. J. (1980). Practical and nonparametric statistics (2th ed.). Inc.: United States.

Content analysis. (2012). Retrieved March 16, 2012, from http://writing.colostate.edu/guides/research/ content/pop2a.cfm

Cooper, S. D., \& Kuypers, J. A. (2004). Embedded versus behind-the-lines reporting on the 2003 Iraq war. In R. D. Berenger (Ed.), Global Media Go to War (pp. 161-172). Spokane, WA: Marquette Books.

Cramer, J. K., \& Thrall, A. T. (2012). Why Did the United States Invade Iraq? A Survey of International Relations and Foreign Policy Scholars. USA. Retrieved April 6, 2014, from http://books.google.com.my /books?id=N2SpAgAAQBAJ\&pg

Diamond, L. (2004). What Went Wrong in Iraq. Foreign Affairs, 83(5), 34-56. http://dx.doi.org/10.2307/20 034066

Dittmer, J. P. (2009). Framing war and a people: A mixed methods study of portrayals of Iraqi violence. Master, University of Oregon, 2009. Retrieved March 1, 2014, from https://scholarsbank.uoregon.edu/

Fried, A. (2005). Terrorism as a Context of Coverage before the Iraq War. The Harvard International Journal of Press/Politics, 10(3), 125-132. http://dx.doi.org/10.1177/1081180X05279509

Fritz, A. J. (2011). Military Women A Content Analysis of United States and United Kingdom Newspapers Portrayal During the Iraq War. Master, East Tennessee State University, 2011. Retrieved Feburary 20, 2014, from http://www.dc.etsu.edu/cgi/viewcontent.cgi?article=2582\&context=etd

Galal, A., Galander, M., \& Auter, P. J. (2008). The Image of the United States Portrayed in Arab World Online Journalism. Paper abstract submitted for consideration to the Ninth International Symposium on Online Journalism. University of Texas at Austin 4-5 April 2008.

Gibbons, J. D., \& Chakraborti, S. (2011). Nonparametric statistical inference (5th ed.). Marcel dekker: United States of America.

Griffin, M. (2004). Picturing America's 'War on Terrorism' in Afghanistan and Iraq: Photographic motifs as news frames. Journalism, 5(4), 381-402. http://dx.doi.org/10.1177/1464884904044201

Hamzah, A. (2008). Trends and future of the Malaysian mass media. Retrieved October 5, 2012, from http://www.ssig.gov.my/ssig/kcent/material/Azizah\%20Hamzah.pdf

Hamzah, A. (2009). Malaysia's Role in National Development: Media Policy and National Stability. Malaysian Journal of Media Studies, 11(1), 49-58.

Harun, R. (2009). In pursuit of national interest: Change and continuity in Malaysia's foreign policy towards the Middle East. Jurnal Antarabangsa Kajian Asia Barat, 1, 23-38.

Hiebert, R. E. (2003). Public relations and propaganda in framing the Iraq war: A preliminary review. Public Relations Review, 29(3), 243-255. http://dx.doi.org/10.1016/S0363-8111(03)00047-X

Holody, K. J. (2011). Constructing the end: Framing and agenda setting of physician assisted suicide. Doctoral dissertation, Bowling Green State University, 2011. Retrieved April 7, 2014, from https://etd.ohiolink.edu/rws_etd/document/get/bgsu1305663580/inline

Ibrahim, F., \& Hashim, R. (1996). Images of Women and Human Rights: A Content Analysis of Malaysian Media During the Fourth World Conference on Women in Beijing. Jurnal Komunikasi, 12, 65-83.

Ibrahim, F., Mustaffa, N., \& Kee, C. P. (2010). Framing a pandemic: Analysis of Malaysian mainstream newspapers in the H1N1 coverage. Journal of Media and Information Warfare, 1(3), 105-122.

Ibrahim, F., Mustaffa, N., Kee, C. P., \& Ahmad, F. (2011). Images and Issues of Superpowers: An Analysis of International News Coverage by the Government-Owned News Agency, Bernama in Four National Dailies 
in Malaysia. The Innovation Journal: The Public Sector Innovation Journal, 16(3), 1-15.

Idid, S. A., \& Kee, C. P. (2012). The Media and Public Agenda among the Malay and Chinese Communities during the 2008 Malaysian General Elections. Asian Social Science, 8(5), 107-115.

Kensicki, L. J. (2000). Second level agenda setting: A study of integration and progress. Egyptian Journal of Public Opinion Research, 1(3), 85-100.

Khalid, K. M. (2003). "September 11" and the changing dynamics of Malaysia-US relations. Asian Review, 16, 91-112.

Küçükcan, T. (2010). Arab Image in Turkey. Seta-foundation for political economic and social research. Report No: 1.

Largio, D. M. (2004). Uncovering the Rationales for the War on Iraq: The Words of the Bush Administration, Congress, and the Media from September 12, 2001 to October 11, 2002. Doctoral dissertation, University of Illinois, 2004. Retrieved April 13, 2014, from http://www.faculty.las.illinois.edu/salthaus/largio_thesis.pdf

Lee, C. H. (2004). News Coverage of the U.S. War with Iraq: A Comparison of the New York Times, the Arab News, and the Middle East Times. Doctoral dissertation, University of Texas at Austin, 2004. Retrieved February 21, 2014, from http://www.lib.utexas.edu/etd/d/2004/leec042/leec042.pdf

Li, X. L. (2012). Images of China: A Comparative Framing Analysis of Australian Current Affairs Programming. Intercultural Communication Studies, XXI(1), 173-188.

Liow, J. (2003). Malaysia's Opposition to the Iraq War: A Matter of Principle or Expediency? Singapore: Institute of Defense and Strategic Studies. Retrieved December 15, 2011, from http://www.idss.edu.sg

McCombs, M. (2004). Setting the agenda: The mass media and public opinion. Polity press: United Kingdom.

McCombs, M. E., \& Shaw, D. L. (1972). The agenda-setting function of mass media. Public opinion quarterly, 36(2), 176-187. http://dx.doi.org/10.1086/267990

Mockaitis, T. R. (2007). The Iraq war: Learning from the past, adapting to the present, and planning for the future. Retrieved March 18, 2012, from http://www.StrategicStudiesInstitute.army.mil/newsletter/

Morris, R. (1994). Computerized Content Analysis in Management Research: A Demonstration of Advantages \& Limitations. Journal of Management, 20(4), 903-931. http://dx.doi.org/10.1016/0149-2063(94)90035-3

Muin, M. J. (2011). Agenda setting theory and the role of the media in shaping public opinion for the Iraq war. Master, University of Central Missouri, 2011. Retrieved April 26, 2014, from http://www.centralspace.ucmo.edu/xmlui/bitstream/.../MMuin_Communication.pdf

Rajaratnam, U. D. (2009) .Role of Traditional and Online Media in the 12th General Election, Malaysia. The Journal of the South East Asia Research Centre for Communications and Humanities, 1(1), 33-58.

Riffe, D., Lacy, S., \& Fico, F. G. (2005). Analyzing Media Messages: Using Quantitative Content Analysis in Research (6th ed.). Lawrence Erlbaum Associates, Inc.

Sani, M. A. M. (2004). Media freedom in Malaysia. Journal of Contemporary Asia, 35(3), 341-367. http://dx.doi. org/10.1080/00472330580000201

Sern, T. J., \& Zanuddin, H. (2011). Reach and Visibility: Perception and Social Marketing of AIDS Patients in Malaysian Media. International Conference on Media and Communication-Communication and Transformation: Progress and Paradox, Universiti Kebangsaan Malaysia 11-12 October 2011.

Shaw, E. (1979). Agenda-setting and mass communication theory. International Journal for Mass Communication Studies, 25(2), 96-105.

SPSS base 10.0 user's guide. (1999). Chicago, United States of America.

Stover, E., Megally, H., \& Mufti, H. (2005). Bremer's "Gordian Knot": Transitional Justice and the US Occupation of Iraq. Human Rights Quarterly, 27(3), 830-857. http://dx.doi.org/10.1353/hrq.2005.0044

Tongco, M. D. (2007). Purposive Sampling as a Tool for Informant Selection. Ethnobotany Research and Applications, 5, 147-158. Retrieved March 8, 2012, from http://hdl.handle.net/10125/227

Wanta, W., Golan, G., \& Lee, C. (2004). Agenda setting and international news: Media influence on public perceptions of foreign nations. Journalism and Mass Communication Quarterly, 81(2), 364-377. http://dx.doi.org/10.1177/107769900408100209

Wimmer, R., \& Dominick, J. (2006). Mass Media Research: An Introduction (8th ed.). United States: Holly J. 
Allen. Retrieved January 20, 2014, from http://www.books.google.com

Wong, K. (2000). Malaysia in the grip of government. Losing control: Freedom of the press in Asia, Asia Pacific Press, Canberra. Retrieved April 6, 2014, from http://www.press.anu.edu.au/wp-content/uploads/2013/11 /Malaysia.pdf

Zeidan, N. F. (2005). Iraqi image in Germany: Field Study. Journal of the College of Arts.

Zheng, L. (2006). Newspaper conformity to national foreign policy coverage of the 2003 Iraq war in the new york times, the times of London and the people's daily (China). Doctoral dissertation, Southern Illinois University Carbondale.

\section{Copyrights}

Copyright for this article is retained by the author(s), with first publication rights granted to the journal.

This is an open-access article distributed under the terms and conditions of the Creative Commons Attribution license (http://creativecommons.org/licenses/by/3.0/). 